\title{
KUALITAS PELAYANAN TERHADAP KEPUASAN PELANGGAN TOKO ONLINE LAZADA (STUDI KASUS: MASYARAKAT KECAMATAN SUKARAMI PALEMBANG)
}

\author{
Amir Hamzah \\ Dosen Politeknik Anika Palembang \\ Email : aham73ck@gmail.com
}

\begin{abstract}
ABSTRAK
Penelitian ini bertujuan untuk mengetahui dan mengkaji kualitas pelayanan terhadap kepuasan pelanggan toko online Lazada di Kecamatan Sukarami Palembang.Alasan peneliti memilih toko online Lazada sebagai objek penelitian karena jaringan e-commerce Lazada berada di berbagai negara di Asia Tenggara termasuk Indonesia. Lazada juga menempati peringkat keempat top e-commerce 2020, dengan jumlah kunjungan ke website Lazada.co.id mencapai 21,4 juta. Penelitian ini adalah penelitian kuantitatif data yang digunakan data primer dan sekunder, metode dan teknik menggunakan Studi pustaka, dengan mengadakan studi penelaahan terhadap buku-buku, literatur-literatur, catatan-catatan, dan laporan-laporan yang ada hubungannya dengan masalah yang dipecahkan. Angket (kuesioner), disebarkan melalui google formulir. Populasi masyarakat kec. Sukarami berjumlah 60 orang. Teknik analisis regresi sederhana, dengan melakukan uji validitas, reliabilitas, uji asumsi klasik dan hipotesis. Hasil pengujian regresi linier sederhana terbentuk persamaan $Y=3,130+0,612 X$, dengan nilai koefisien determinasi $\left(R^{2}\right)$ sebesar 0,527 atau 52,7\%, menunjukkan bahwa kualitas pelayanan dapat menjelaskan kepuasan pelanggan sebesar 52,7\% sedangkan sisanya 47,3\% dijelaskan oleh variabel lain yang tidak termasuk dalam penelitian ini.
\end{abstract}

Kata Kunci : online, Lazada, Kepuasan pelanggan dan Kualitas pelayanan

\section{PENDAHULUAN}

Di kutip dari(Kompas.com 2021), pengguna internet di Indonesia pada tahun 2021 mencapai 202,6 juta atau $73,7 \%$ dari total populasi sebesar 274,9 juta jiwa pada bulan Januari. Melansir dari Sirclo.com, jumlah pengguna internet yang aktif berbelanja online pada tahun 2020 mencapai 88\%(E-commerce 2020). Sehingga tidak dapat dipungkiri banyak penduduk terutama di Indonesia yang meningkatkan bisnis melalui media elektronik yang bersifat online. Salah satu wujud $e$ business yang sangat dikenal publik yakni aktivitas perdagangan secara elektronik ataupun yang dikenal dengan istilahelectronic commerce atau e-commerce.

E-commerce adalah kegiatan-kegiatan bisnis yang menyangkut konsumen (consumers), manufaktur (manufactures), service providers dan pedagang perantara (intermediaries) dengan menggunakan jaringan-jaringan komputer (computer networks) yaitu internet. Menurut (Ahmad 2017:53-62) mendeskripsikan e-commerce sebagai salah satu jenis dari mekanisme bisnis secara elektronik yang berfokus pada transaksi bisnis berbasis individu dengan menggunakan internet sebagai media pertukaran barang atau jasa. E-commerce membawa peluang bisnis yang besar (seperti penjualan produk dan penyediaan layanan online) dan pertumbuhan pendapatan.

Di Indonesia sendiri ada banyak situs E-commerce yang menawarkan berbagai jenis produk, baik barang maupun jasa. Shopee, Tokopedia, Bukalapak, Lazada, Blibli, JD.id, Orami, Bhinneka, Sociolla, dan Zalora adalah 
sepuluh (10) e-commerce yang paling sering di kunjungi(Christy 2020). Dalam penelitian ini peneliti memilih toko online Lazada sebagai objek penelitian. Menurut website Grahanurdian (Nurdian 2020), penggunaan $e$ commerce meningkat dengan total populasi $1,1 \%$ menjadi 2,9 juta pada 2019 , penggunaan smartphone yang terkoneksi $4,6 \%$ atau 1 juta, pengguna internet $17 \%$ atau 25 juta, dan pengguna media sosial $8,1 \%$ atau 12 juta.

Alasan peneliti memilih toko online Lazada sebagai objek penelitian karena jaringan e-commerce Lazada berada di berbagai negara di Asia Tenggara termasuk Indonesia. Lazada juga menempati peringkat keempat top e-commerce 2020, dengan jumlah kunjungan ke website Lazada.co.id mencapai 21,4 juta. Selain itu Lazada juga menempati posisi kedua top download dan pengguna aktif bulanan di Asia Tenggara. Mengutip dari Dailysocial.id, pada Q4 2020 toko online Lazada memiliki jumlah like terbanyak hingga 30 juta pada media sosial facebook (Nabila 2021).

Lazada merupakan salah satu pusat perbelanjaan online dengan konsep produk yang lengkap dan pembelian yang mudah. Lazada menawarkan berbagai macam produk termasuk elektronik, fashion, perawatan kulit, pulsa, perlengkapan ibu dan anak serta perlengkapan olahraga. Toko online Lazada juga selalu memberikan penawaran yang menarik seperti, harga promo, diskon khusus, dan juga memberikan kemudahan transaksi dengan gratis ongkos kirim untuk area tertentu, layanan cash on delivery (COD), serta garansi uang kembali jika barang tidak sesuai. Agar para pelanggan yang berbelanja ditoko online Lazada merasa puas tentu saja harus menciptakan kualitas pelayanan yang baik.

Menurut (Chandra, Gregorius 2011:164) kualitas pelayanan dianggap sebagai ukuran kesempurnan sebuah produk atau jasa yang terdiri dari kualitas desain dan kualitas kesesuaian (conformance quality). (Tjiptono 2011:157), kualitas pelayanan itu sendiri ditentukan oleh kemampuan perusahaan dalam memenuhi kebutuhan pelanggan sesuai dengan ekspektasi pelanggan. Faktor yang mempengaruhi kualitas pelayanan adalah pelayanan yang diharapkan dan pelayanan yang di terima. Apabila pelayanan yang diterima sesuai bahkan dapat memenuhi apa yang diharapkan maka jasa dapat dikatakan baik atau positif.Berdasarkan latar belakang masalah tersebut, maka peneliti bermaksud meneliti apakah kualitas pelayanan berpengaruh terhadap kepuasan pelanggan toko online Lazada.

\section{TINJAUAN PUSTAKA \\ 2.1 Kualitas Pelayanan \\ 2.1.1 Definisi Kualitas Pelayanan}

Menurut (Kotler 2016:214) layanan didefinisikan sebagai seluruh tindakan atau kinerja yang dapat diberikan satu pihak kepada pihak lain yang pada intinya tidak berwujud dan tidak menghasilkan kepemilikan apapun.Menurut (Tjiptono 2012:157) mendefinisikan kualitas pelayanan adalah ukuran seberapa bagus tingkat layanan yang diberikan mampu sesuai dengan ekspektasi pelanggan. Definisi lain kualitas pelayanan menurut Wyckof dalam Lovelock yang dikutip oleh (Tjiptono 2012:270) merupakan tingkat keunggulan (excellence) yang diharapkan dan pengendalian atas keunggulan tersebut untuk memenuhi keinginan pelanggan. Kualitas pelayanan menurut (Hanif 2013:67) adalah seberapa jauh perbedaan antara kenyataan dan harapan pelanggan atas langganan yang mereka terima atau peroleh.

Dari definisi diatas dapat disimpulkan bahwa kualitas pelayanan adalah suatu upaya pemenuhan kebutuhan dan keinginan konsumen, serta ketepatan dalam penyampaiannya untuk mengimbangi harapan konsumen, yaitu adanya kesesuaian dengan harapan dan adanya kesesuaian pelayanan yang diberikan dengan pelayanan yang diterima oleh konsumen. 


\subsubsection{Faktor-faktor yang Mempengaruhi Kualitas Pelayanan}

Kualitas pelayanan yang baik juga merupakan salah satu faktor kunci keberhasilan perusahaan sektor jasa (Nasution 2019). Menurut (Tjiptono 2002:43) faktorfaktor yang perlu diperhatikan dalam meningkatkan kualitas pelayanan adalah:mengidentifikasi determinan utama kualitas layanan, mengelola ekspektasi pelanggan, mengelola bukti kualitas layanan, mendidik konsumen tentang layanan, menumbuhkan budaya kualitas, menciptakan automating quality, menindaklanjuti layanan, mengembangkan sistem informasi kualitas layanan dan sistem informasi.

\subsubsection{Dimensi Kualitas Pelayanan}

Menurut Parasuraman yang dikutip oleh (Tjiptono 2011:198), ada lima dimensi pokok dalam kualitas pelayanan yaitu sebagai berikut:

a. Bukti Fisik(tangible)

Karena suatu pelayanan tidak dapat dilihat, diraba dan dicium, akan tetapi dapat dirasakan sehingga aspek tangible (bukti fisik) menjadi penting sebagai ukuran pelayanan. Pelanggan akan menggunakan visi tersebut untuk menilai kualitas pelayanan. Tangibility yang baik mempengaruhi persepsi pelanggan. Indikator dari tangible adalah sebagai berikut:Penampilan petugas/aparatur dalam melayani pelanggan, Kenyamanan tempat melakukan pelayanan, Kemudahan dalam proses pelayanan dan Kedisiplinan petugas/aparatur dalam melakukan pelayanan, Kemudahan akses pelanggan dalam permohonan pelayanan serta Penggunaan alat bantu dalam pelayanan.

b. Kehandalan (reliability)

Reliability mencakup konsistensi penampilan dari kehandalan jasa untuk memberikan pelayanan sesuai dengan yang dijanjikan secara terpercaya dan akurat.
Indikator dari relability adalah: Kecermatan petugas dalam melayani, Memiliki standar pelayanan yang jelas, Kemampuan petugas/aparatur dalam menggunakan alat bantu dalam proses pelayanan dan Keahlian petugas dalam menggunakan alat bantu dalam proses pelayanan.

c. Daya Tanggap (responsiveness)

Responsiveness adalah dimensi kualitas pelayanan yang paling dinamis. Harapan pelanggan terhadap kecepatan pelayanan akan meningkat dari waktu ke waktu. Kepuasan terhadap aspek respon didasarkan pada persepsi, bukan kenyataan. Secara ringkas responsiveness meliputi kesiapan dan kecepatan tanggapan petugas untuk menyediakan jasa. Indikator dari responsiveness adalah:Merespon setiap pelanggan/pemohon yang ingin mendapatkan pelayanan, Petugas/aparatur melakukan pelayanan dengan cepat, Petugas/aparatur melakukan pelayanan dengan tepat, Petugas/aparatur melakukan pelayanan dengan cermat, Petugas/aparatur melakukan pelayanan dengan waktu yang tepat, Semua keluhan pelanggan direspon oleh petugas.

\section{d. Jaminan dan Kepastian (assurance)}

Assurance atau jaminan, adalah dimensi yang berhubungan dengan kemampuan perusahaan dan perilaku front-line staf dalam menanamkan rasa percaya dan keyakinan kepada para pelanggannya. Indikator dari assurance adalah: Petugas memberikan jaminan tepat waktu dalam pelayanan, Petugas memberikan jaminan biaya dalam pelayanan, Petugas memberikan jaminan legalitas dalam pelayanan dan Petugas memberikan jaminan kepastian biaya dalam pelayanan. 


\section{e. Empati (empathy)}

Dimensi empathy adalah dimensi yang memberikan peluang besar untuk memberikan pelayanan yang bersifat sureprise. Secara ringkas empathy adalah mencakup kemudahan komunikasi, dan pemahaman terhadap kebutuhan konsumen dengan cara mendengarkan kemudian memberi perhatian kepada tiap-tiap consumer.

\subsection{Kepuasan Pelanggan}

\subsubsection{Definisi Kepuasan Pelanggan}

Menurut (Irawan 2009:02) kepuasan (Satisfaction) dalam bahasa latin yaitu satis yang berarti enough atau cukup dan farece yang berarti to do atau melakukan. Produk atau jasa yang dapat memuaskan adalah produk atau jasa yang mampu memberikan sesuatu yang dicari oleh konsumen sampai pada tingkat cukup. Kepuasan merupakan hasil dari penilaian konsumen bahwa produk atau pelayanan telah memberikan tingkat kenikmatan dimana tingkat pemenuhan ini bias lebih atau kurang.

Menurut (Tse dan wilton 2008:24), menyatakan bahwa kepuasan atau ketidakpuasan pelanggan adalah respon pelanggan terhadap evaluasi ketidak sesuaian (disconfirmation) yang dirasakan antara harapan sebelumnya dan kinerja aktual produk yang dirasakan setelah pemakaiannya.Menurut (Tjiptono 2008:24)menyatakan kepuasan pelanggan merupakan evaluasi purna beli dimana alternatif yang dipilih sekurangkurangnya sama atau melampui harapan pelanggan, sedangkan ketidakpuasan timbul apabila hasil (autcome) tidak memenuhi harapan.

Definisi diatas dapat disimpulkan bahwa pada dasarnya kepuasan pelanggan mencakup perbedaan antar harapan dan kinerja atau hasil yang dirasakan.

\subsubsection{Faktor-faktor yang Mempengaruhi Kepuasan Pelanggan \\ Menurut (Lupiyoadi 2006:18) dalam} menentukan kepuasan konsumen ada lima faktor yang harus diperhatikan oleh perusahaan antara lain sebagai berikut:Kualitas produk, Kualitas pelayanan atau jasa. Salah satu konsep service quality yang populer adalah servqual. Berdasarkan konsep ini service quality mempunyai 5 (dimensi) yaitu reliability, resvonsiveness, assurance, empaty, dan tangible. Selanjutnya Emosi, Harga dan Biaya

\subsubsection{Indikator Kepuasan Pelanggan}

Indikator kepuasan pelanggan menurut Hawkins dan Lonney dalam (Tjiptono 2015:101) yaitu sebagai berikut:Kesesuaian harapan merupakan tingkat kesesuaian antara kinerja produk yang diharapkan oleh pelanggan dengan yang dirasakan oleh pelanggan. Minat berkunjung kembali merupakan kesediaan pelanggan untuk melakukan pembelian ulang terhadap produk. Terakhir adalah kesediaan merekomendasikanmerupakan kesediaan pelanggan untuk merekomendasikan produk yang dirasakannya kepada teman atau keluarga.

\subsubsection{Hubungan antara Kualitas Pelayanan dengan KepuasanPelanggan}

Menurut (Payne 2000:25) kualitas pelayanan terhadap kepuasan pelanggan memiliki hubungan yang sangat erat, yaitu kualitas memberikan suatu dorongan kepada pelanggan untuk menjalin hubungan dengan perusahaan. Kepuasan pelanggan terbentuk dari kualitas pelayanan, dimana kualitas pelayanan sebagai bahan evaluasi secara keseluruhan untuk menilai kepuasan pelanggan setelah melakukan transaksi. Menurut (Kotler 2012:153) kualitas produk dan pelayanan, kepuasan pelanggan dan profitabilitas perusahaan berhubungan erat. Semakin tinggi hasil kepuasan menghasilkan 
tingkat kepuasan pelanggan yang lebih tinggi, dimana membantu tingginya harga dan pengurangan pengeluaran.

\subsection{Penelitian Terdahulu}

Beberapa penelitian terdahulu menjadi rujukan penelitian ini antara lain, penelitian Julia Ramadani Nasution (2019) yang meneliti analisis kualitas pelayanan terhadap kepuasan pelanggan toko online Lazada. Variabel dalam penelitian ini adalah kualitas pelayanan sebagai variabel independen (X) dan kepuasan pelanggan sebagai variabel dependen (Y). Hasil dari penelitian tersebut menunjukan bahwa seluruh variabel kualitas pelayanan berpengaruh signifikan terhadap kepuasan pelanggan toko online Lazada. Hal tersebut dapat dilihat dari koefisien determinasi sebesar 0,529 yang berarti kepuasan pelanggan toko online Lazada dapat dijelaskan oleh variabel kualitas pelayanan sebesar $52,9 \%$.

Hasil penelitian Nugroho (2018) mengungkap pengaruh kualitas layanan terhadap kepuasan pelanggan jasa pengiriman Lazada Express saat harbolnas di $E$ Commerce. bahwa kualitas layanan berpengaruh positif terhadap kepuasan pelanggan. Hal tersebut dapat dilihat dari koefisien determinasi menunjukkan hasil bahwa kemampuan variabel layanan menjelaskan tingkat kepuasan pelanggan sebesar 85,9\%. Kemudian i Andoyo (2020) yang meneliti pengaruh harga dan kualitas pelayanan terhadap kepuasan konsumen toko online Lazada di Universitas Muhammadiyah Palembang. Variabel dalam penelitian ini adalah harga (X1) dan kualitas pelayanan (X2) sebagai variabel dependen, kepuasan pelanggan (Y) sebagai variabel dependen. Hasil penelitian tersebut menunjukkan bahwa ada pengaruh yang signifikan antara variabel harga dan kualitas pelayanan terhadap variabel kepuasan konsumen. Hasil penelitian tersebut menunjukkan bahwa koefisien determinasi sebesar 0,642 menunjukkan bahwa karakteristik harga dan kualitas pelayanan mampu menjelaskan kepuasan konsumen sebesar $64,2 \%$. Selanjutnya penelitian Cahyani, dkk (2015) bahwa kepuasan kerja terhadap kualitas pelayanan internal tenaga pendidik pada politeknik swasta di sumatera selatanmemilikipengaruhsignifikan

\subsection{Kerangka Pemikiran Teoritis}

Kerangka pemikiran teoritis dalam penelitian ini sebagai berikut

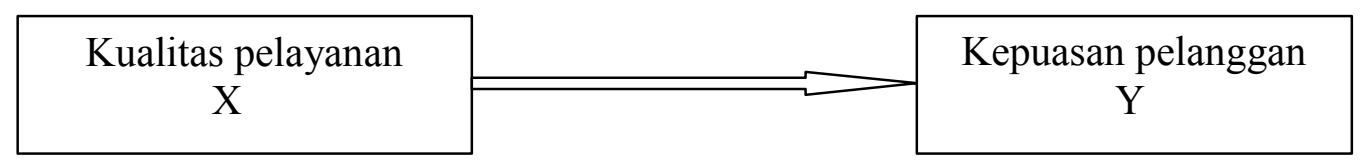

\section{Gambar 2. 1 \\ Variabel Penelitian}

\subsection{Hipotesis}

Hipotesis merupakan suatu ide untuk mencari fakta yang harus dikumpulkan. Hubungan antara variabel dalam penelitian ini memiliki hipotesis sebagai berikut:Ho: Tidak ada pengaruh kualitas pelayanan terhadap kepuasan pelanggan dan Ha: Adanya pengaruh kualitas pelayan terhadap kepuasan pelanggan.

\section{METODOLOGI PENELITIAN 3.1 Metode Penelitian}

Metode penelitian yang digunakan dalam penelitian ini adalah metode penelitian kuantitatif. Data kuantitatif menurut (Sugiyono 2010:15) adalah jenis data yang dapat diukur atau dihitung secara langsung, yang berupa informasi atau penjelasan yang dinyatakan 
dengan bilangan atau berbentuk angka. data tersebut kemudian diolah menggunakan uji statistik.

\subsection{Lokasi Penelitian}

Penelitian ini dilaksanakan di wilayah Kecamatan Sukarami Palembang. Kecamata Sukarami Palembang terdiri dari beberapa kelurahan yaitu Kebun Bunga, Sukabangun, Sukajaya, Sukarami, Sukodadi, Talang Betutu, dan Talang Jambe.

\subsection{Variabel Penelitian dan Definisi Operasional}

Dalam penelitian ini ada dua variabel yang digunakan yaitu:kualitas pelayanan (X). dan kepuasan pelanggan (Y).Adapun definisi operasional dalam penelitian ini yaitu Kualitas Pelayanan (X) dan Kepuasan Pelanggan (Y). Kualitas pelayanan adalah ukuran seberapa baik tingkat layanan yang diberikan mampu memenuhi harapan pelanggan. Menurut Parasuraman yang dikutip oleh (Tjiptono 2011:198) indikator dari variabel ini adalah: Bukti Fisik(tangible); Kehandalan (reliability); Daya Tanggap (responsiveness); Jaminan dan Kepastian (assurance);Empati (empathy). Indikator dari kepuasan pelanggan adalah: Kesesuaian harapan; Minat berkunjung kembali; Kesediaan merekomendasikan. Indikator-indikator diatas diukur dengan skala likert yang memiliki lima tingkat preferensi jawaban yang masing-masing mempunyai skor 1-5 dengan 1 = Sangat Tidak Setuju (STS), 2 = Tidak Setuju (TS), $3=\operatorname{Netral}(\mathrm{N}), 4=$ Setuju (S)dan 5 = Sangat Setuju (SS)

\subsection{Populasi dan Sampel}

Populasi dalam penelitian ini adalah masyarakat Kecamatan Sukarami Palembang.Menurut (Sugiyono, 2017:81), sampel adalah bagian dari jumlah dan sifat yang dimiliki oleh suatu populasi. Pengambilan sampel dilakukan dengan pertimbangan bahwa populasi yang ada sangat besar jumlahnya sehingga tidak memungkinkan untuk meneliti seluruh populasi yang ada, oleh karena itu dibentuk sebuah perwakilan populasi. Teknik pengambilan sampel dalam penelitian ini menggunakan non probability sampling yaitu teknik yang tidak memberikan kesempatan sama bagi setiap unsur atau anggota populasi untuk dijadikan sampel. Penentuan pengambilan sampel jumlah responden dilakukan menggunakan teknik accidential sampling (sampel kebetulan). Accidential sampling adalah teknik penentuan sampel berdasarkan kebetulan, yaitu siapa saja yang secara kebetulan bertemu dengan peneliti dapat digunakan sebagai sampel.

Penentuan besarnya sampel menurut (Ferdinand 2014:173), membutuhkan paling sedikit lima (5) indikator. Dalam penelitian ini terdapat dua belas (12) indikator.Rumus: $\mathrm{n}=($ $5 \mathrm{x}$ jumlah indikator yang digunakan $), \mathrm{n}=(5 \mathrm{x}$ 12 indikator) $=60$ sampel. Hasil perhitungan persamaan diatas dapat diperoleh jumlah sampel yang akan diteliti adalah 60 responden.

\subsubsection{Jenis dan Sumber Data}

Data kuantitatif menurut (Sugiyono 2010:15) adalah jenis data yang dapat diukur atau dihitung secara langsung, yang berupa informasi atau penjelasan yang dinyatakan dengan bilangan atau berbentuk angka.Sumber Data, ada dua macam yaitu data primer dan data sekunder.

\subsubsection{Teknik Pengumpulan Data}

Teknik pengumpulan data yang digunakan adalah Studi pustaka, dengan mengadakan studi penelaahan terhadap bukubuku, literatur-literatur, catatan-catatan, dan laporan-laporan yang ada hubungannya dengan masalah yang dipecahkan. Angket (kuesioner), dalam penelitian ini penulis menggunakan google formulir untuk membuat angket dan menyebarkannya kepada responden. Wawancara, dengan cara tanya jawab secara 
langsung dengan subjek yang berkontribusi langsung dengan objek yang diteliti.

\subsection{Teknik Analisis Data}

Penelitian ini menggunakan teknik analisis regresi linier sederhana, karena variabel yang terlibat dalam penelitian ini ada dua, yaitu kualitas pelayanan sebagai variabel bebas yang di lambangkan dengan $\mathrm{X}$ serta kepuasan pelanggan sebagai variabel terikat yang dilambangkan dengan $\mathrm{Y}$.

\subsubsection{Uji Validitas}

Menurut (Ghozali 2018:51) uji validitas digunakan untuk mengukur sahat atau valid tidaknya suatu kuesioner. Sebuah instrumen atau kuesioner dikatakan valid jika pertanyaan pada instrumen atau kuesioner mampu mengungkapkan sesuatu yang akan diukur oleh kuesioner tersebut. Tingkat validitas dapat diukur dengan cara membandingkan nilai rhitungpada tabel Correlations pada total nilai pearson correlations untuk setiap indikator variabel dengan nilai rtabeldengan ketentuan untuk degree of freedom $(\mathrm{df})=\mathrm{n}-\mathrm{k}$, dimana $\mathrm{n}$ adalah jumlah sampel yang digunakan dan $\mathrm{k}$ adalah jumlah variabel independennya. Dengan jumlah sampel (n) dan tingkat signifikansi 0,05 maka rtabel pada penelitian ini adalah: $r(0,05 ; 60-1)=59$.

Untuk menentukan apakah suatu item layak digunakan, biasanya dilakukan uji signifikansi koefisien korelasi pada taraf signifikansi 0,05 yang artinya suatu item dianggap valid jika berkorelasi signifikan terhadap skor total. Jika rhitung $>$ rtabel dan nilai positif maka butir atau pertanyaan atau variabel tersebut dinyatakan valid. Sebaliknya, jika rhitung $<$ rtabel, maka butir atau pertanyaan atau variabel tersebut dinyatakan tidak valid.

\subsubsection{Uji Reliabilitas}

Reliabilitas sebenarnya adalah alat untuk mengukur suatu kuesioner yang merupakan indikator dari variabel atau konstruk. Suatu kuesioner dikatakan reliabel atau handal jika jawaban seseorang terhadap pernyataan adalah konsisten atau stabil dari waktu ke waktu. Dengan kriteria pengambilan keputusan sebagaimana dinyatakan oleh (Ghozali, 2018:46), yaitu jika koefisien Cronbach Alpha $>0,70$ maka pertanyaan dinyatakan handal atau suatu konstruk maupun variabel dinyatakan reliabel. Sebaliknya, jika koefisien Cronbach Alpha $<0,70$ maka pertanyaan dinyatakan tidak handal.

\subsubsection{Uji Asumsi Klasik}

Untuk menguji penyimpangan asumsi klasik tersebut dapat menggunakan cara untuk mengujinya sebagai berikut: Uji normalitas untuk mengetahui apakah sampel yang diambil berasal dari populasi yang terdistribusi normal. Uji Autokorelasi untuk mengetahui apakah dalam persamaan regresi terdapat kondisi serial atau tidak antara variabel pengganggu. Jika nilai Run $>0,05$ maka gejala autokorelasi dapat diabaikan. Model regresi yang baik mensyaratkan tidak adanya autokorelasi. Uji Multikolinearitas untuk variabel bebas, di mana korelasi antar variabel bebas dilihat. Jika ada dua variabel bebas di mana kedua variabel tersebut berkorelasi sangat kuat, maka secara logika persamaan regresinya cukup diwakili oleh satu variabel saja. korelasi yang sangat kuat yang dimaksud adalah apabila nilai $\mathrm{r}>$ 0,90. Jadi apabila korelasi antar variabel kurang dari 0,90 dinyatakan tidak terjadi multikolinearitas.

Terakhir Uji Heterokedastisitas untuk melihat apakah kesalahan (eror) pada data kita memiliki varians yang sama atau tidak. Dasar pengambilan keputusan adalah titik-titik menyebar di atas dan di bawah atau disekitar 0 , titik-titik tidak mengumpul hanya diatas atau dibawah saja, penyebaran titik-titik data tidak membentuk pola bergelombang melebar kemudian menyempit kembali, dan penyebaran titik-titik data tidak berpola maka tidak terjadi heteroskedastisitas. 


\subsubsection{Regresi Linier Sederhana}

Analisis regresi linier sederhana digunakan untuk menguji sifat hubungan sebab-akibat antara variabel independen (X) terhadap variabel dependen (Y) yang diformulasikan dalam bentuk persamaan sebagai berikut: $\mathrm{Y}=\mathrm{a}+\mathrm{bx}$

dimana :

$\mathrm{Y}=$ Variabel Response atau Variabel Akibat (Dependent)

$\mathrm{X}=$ Variabel Predictor atau Variabel Faktor Penyebab (Independent)

$\mathrm{a}=$ konstanta

$\mathrm{b}=$ koefisien regresi (kemiringan); besaran Response ditimbulkan oleh Predictor.

\subsubsection{Uji Hipotesis}

Uji Signifikan Parameter Individual (Uji Statistik t), Bentuk pengujiannya adalah $\mathrm{H}_{\mathrm{o}}$ : artinya variabel bebas $\mathrm{X}$, yaitu kualitas pelayanan secara parsial tidak berpengaruh positif dan signifikan terhadap variabel terikat (Y) yaitu kepuasan pelanggan. $\mathrm{H}_{\mathrm{a}}$ : artinya variabel bebas $\mathrm{X}$, yaitu kualitas pelayanan secara parsial berpengaruh positif dan signifikan terhadap variabel terikat (Y) yaitu kepuasan pelanggan. Kriteria dalam pengujian dengan tingkat signifikasi $(\alpha)=0,05$.

Koefisien determinasi $\left(\mathrm{R}^{2}\right)$ dimaksud untuk mengetahui tingkat ketepatan yang paling baik dalam analisa regresi, hal ini ditunjukkan oleh besarnya koefisien determinasi $\left(\mathrm{R}^{2}\right)$ antara 0 (nol) sampai 1 (satu). Jika koefisien determinasi 0 (nol) berarti variabel independen sama sekali tidak berpengaruh terhadap variabel dependen. Apabila koefisien determinasi semakin mendekati 1 (satu), maka dapat dikatakan bahwa variabel independen berpengaruh terhadap variabel dependen. Karena variabel independen hanya 1 (satu), maka koefisien determinasi yang digunakan adalah $R$ Square.

\section{HASIL DAN PEMBAHASAN \\ 4.1 Hasil Penelitian \\ 4.1.1 Deskripsi Responden}

Reponden dari penelitian ini adalah masyarakat Kecamatan Sukarami Palembang. Adapun pertanyaan yang termuat dalam kuesioner ini terdiri dari dua bagian, yaitu pertanyaan mengenai identitas responden dan pertanyaan mengenai variabel independen yaitu kualitas pelayanan dan variabel dependen yaitu kepuasan pelanggan. Pada bagian ini akan dijelaskan mengenai identitas responden berdasarkan jenis kelamin dan umur. Berdasarkan data primer yang telah diolah, maka hasil persebaran responden berdasarkan jenis kelamin dalam penelitian ini dapat dilihat dalam tabel berikut.

\section{Tabel 4. 1Responden Berdasarkan Jenis Kelamin}

\begin{tabular}{|c|c|c|c|c|c|}
\hline & & Frequency & Percent & Valid Percent & Cumulative Percent \\
\hline \multirow[t]{3}{*}{ Valid } & Laki-laki & 22 & 36,7 & 36,7 & 36,7 \\
\hline & Perempuan & 38 & 63,3 & 63,3 & 100,0 \\
\hline & Total & 60 & 100,0 & 100,0 & \\
\hline
\end{tabular}

Sumber: Data primer yang diolah dengan SPSS 25.0, 2021

Berdasarkan dari data tabel 4.1 dapat disimpulkan bahwa pelanggan toko online Lazada di Kecamatan Sukarami Palembang dari 60 responden berdasarkan jenis kelamin, yaitu $36,7 \%$ berjenis kelamin laki-laki.
Sedangkan sisanya $63,3 \%$ berjenis kelamin perempuan yang artinya pelanggan toko online Lazada di Kecamatan Sukarami Palembang lebih banyak perempuan. 
Tabel 4. 2

Responden Berdasarkan Usia

\begin{tabular}{ll|r|r|r|r} 
& & Frequency & Percent & Valid Percent & \multicolumn{1}{c}{ Cumulative Percent } \\
\hline \multirow{5}{*}{ Valid } & 17-22 Tahun & 22 & 36,7 & 36,7 & 36,7 \\
\cline { 2 - 6 } & 23-29 Tahun & 24 & 40,0 & 40,0 & 76,7 \\
\cline { 2 - 6 } & 30-35 Tahun & 14 & 23,3 & 23,3 & 100,0 \\
\cline { 2 - 6 } & Total & 60 & 100,0 & 100,0 & \\
\hline
\end{tabular}

Sumber: Data primer yang diolah dengan SPSS 25.0, 2021

Berdasarkan data dari tabel 4.2 dapat disimpulkan bahwa pelanggan toko online Lazada di Kecamatan Sukarami Palembang dari 60 responden $36,7 \%$ berusia 17-22 tahun, $40 \%$ berusia $23-29$ tahun dan sisanya $23,3 \%$ berusia 30-35 tahun.

\subsubsection{Analisis Data}

\section{a. Hasil Uji Validitas}

Uji validitas akan menguji masingmasing variabel yang digunakan dalam penelitian ini, dimana keseluruhan penelitian memuat 12 pertanyaan yang harus dijawab oleh responden. Adapun kriteria yang digunakan dalam penelitian ini adalah sebagai berikut: tingkat kepercayaan 95\% $(\alpha=5)$, derajat kebebasan $(\mathrm{df})=\mathrm{n}-1=60-1=59$, didapat rtabel $=0,2126$. Jika rhitung (untuk setiap butir pertanyaan dapat dilihat pada kolom corrected item - Total Correlation) lebih besar dari rtabel dan nilai r positif, maka hasil pengujian validitas dapat di tunjukan pada tabel berikut :

Tabel 4. 3Hasil Uji Validitas Variabel Penelitian

\begin{tabular}{|c|c|c|c|c|}
\hline Variabel & Item Pertanyaan & r hitung & r tabel & Keterangan \\
\hline Kualitas & 1 & 0,743 & 0,2126 & Valid \\
\cline { 2 - 5 } Pelayanan & 2 & 0,527 & 0,2126 & Valid \\
\cline { 2 - 5 } & 3 & 0,568 & 0,2126 & Valid \\
\cline { 2 - 5 } & 4 & 0,573 & 0,2126 & Valid \\
\cline { 2 - 5 } & 5 & 0,638 & 0,2126 & Valid \\
\cline { 2 - 5 } & 6 & 0,606 & 0,2126 & Valid \\
\cline { 2 - 5 } & 7 & 0,698 & 0,2126 & Valid \\
\hline
\end{tabular}

\begin{tabular}{|c|c|c|c|c|}
\hline Variabel & Item Pertanyaan & r hitung & r tabel & Keterangan \\
\hline Kepuasan & 1 & 0,796 & 0,2126 & Valid \\
\cline { 2 - 5 } Pelanggan & 2 & 0,540 & 0,2126 & Valid \\
\cline { 2 - 5 } & 3 & 0,762 & 0,2126 & Valid \\
\cline { 2 - 5 } & 4 & 0,855 & 0,2126 & Valid \\
\cline { 2 - 5 } & 5 & 0,482 & 0,2126 & Valid \\
\hline
\end{tabular}

Sumber: Data primer yang diolah dengan SPSS 25.0, 2021

Berdasarkan tabel 4.3 dapat diketahui bahwa nilai rhitung lebih besar dari rtabel keseluruhan indikator yang diuji bernilai positif dan dapat diambil kesimpulan bahwa keseluruhan butir indikator yang digunakan 
dalam penelitian ini lolos uji validitas dan dinyatakan valid.

\section{a. Hasil Uji Reliabilitas}

Uji reliabilitas untuk mengukur konsistensi konstruk atau variabel penelitian. Untuk mengukur uji reliabilitas dilakukan dengan menggunakan uji statistik koefisien Cronbach Alpha ( $\alpha$ ), suatu variabel dikatakan reliabel jika memberikan nilai koefisien Alpha lebih besar dari pada 0,70 (Ghozali, 2018:46). Hasil uji reliabilitas dalam penelitian ini dapat dilihat pada tabel di bawah ini :

Tabel 4. 4

Hasil Uji Reliabilitas Variabel Penelitian

\begin{tabular}{|l|c|c|c|}
\hline \multicolumn{1}{|c|}{ Variabel Penelitian } & Cronbach Alpha & Cut Of Value & Keterangan \\
\hline Kualitas Pelayanan & 0,730 & 0,70 & Reliabel \\
\hline Kepuasan Pelanggan & 0,720 & 0,70 & Reliabel \\
\hline
\end{tabular}

Sumber: Data primer yang diolah dengan SPSS 25.0, 2021

Hasil pengujian reliabilitas pada tabel 4.4 di atas menunjukkan bahwa nilai koefisien Alpha dan variabel-variabel yang diteliti menunjukkan hasil yang beragam, akan tetapi semua item pertanyaan variabel independen (X) dan variabel dependen (Y) tersebut memiliki nilai koefisien Alpha lebih besar 0,70. Dengan demikian dapat disimpulkan bahwa alat ukur yang digunakan dalam penelitian ini adalah reliabel.

\subsubsection{Uji Asumsi Klasik} a. Uji Multikolonieritas

Uji multikolonieritas bertujuan untuk menguji apakah dalam model regresi ditemukan adanya korelasi antar variabel bebas (independen). Model regresi yang baik seharusnya tidak terjadi korelasi antara veriabel bebas. Menurut Ghozali (2013:106) nilai Variance Inflation Factor (VIF) untuk multikolonieritas adalah $<10$ dan nilai tolerance $>0,10$. Hasil uji multikolonieritas tertera pada tabel 4.5 .

Tabel 4. 5

Hasil Nilai VIF dan Angka Tolerance

\begin{tabular}{|c|c|c|}
\hline Variabel Penelitian & VIF & Tolerance \\
\hline Kualitas Pelayanan & 1,000 & 1,000 \\
\hline
\end{tabular}

Sumber: Data primer yang diolah dengan SPSS 25.0, 2021

Tabel 4.5 diatas terlihat bahwa nilai VIF $<10$ dan angka tolerance $>0,10$ yang berarti tidak terdapat korelasi pada variabel bebas, maka dapat disimpulkan bahwa tidak ada multikolonieritas antar variabel independen dalam regresi. Dengan kata lain model regresi dalam penelitian ini bebas dari gejala multikolonieritas.

\section{a. Uji Normalitas}

Uji normalitas bertujuan untuk menguji apakah dalam model regresi variabel dependen dan independen keduanya mempunyai distribusi normal atau tidak. Analisis grafik dilakukan dengan melihat histogram dan normal probability plot. Jika data (titik) menyebar disekitar garis diagonal dan mengikuti arah garis diagonal, maka menunjukkan model regresi memenuhi asumsi normalitas (Ghozali, 2005:110). 


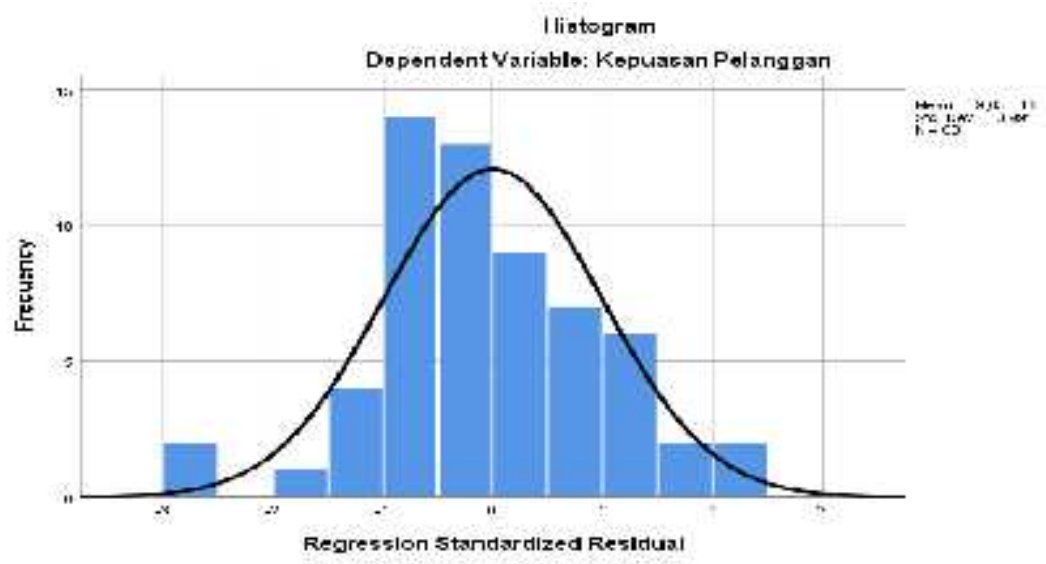

Gambar 4. 1 Histogram

Sumber: Data primer yang diolah dengan SPSS 25.0, 2021

Dengan melihat tampilan grafik histogram diatas dapat dilihat dan disimpulkan bahwa grafik histogram menunjukkan pola distribusi normal dan berbentuk simetris, tidak melenceng (Skewnes) ke kanan dan ke kiri.

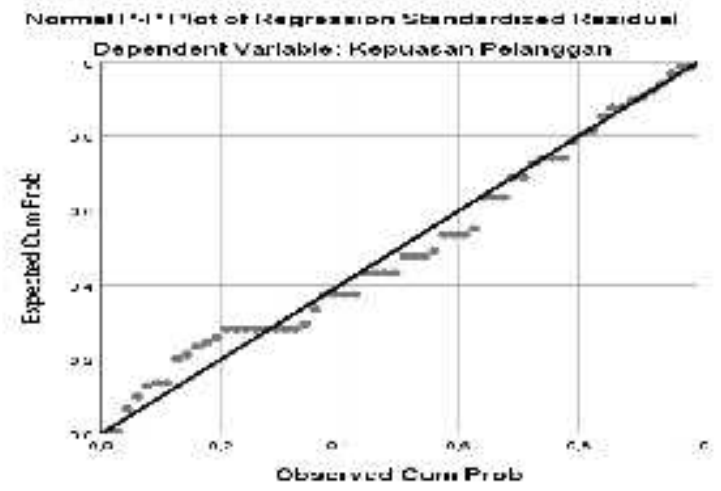

Gambar 4. 2 Grafik Normal Probability Plot

Sumber: Data primer yang diolah dengan SPSS 25.0, 2021

Pada grafik normal probability plot di atas terlihat titik-titik menyebar berhimpit disekitar garis diagonal, serta penyebaran mengikuti arah garis diagonal atau grafik histogramnya menunjukkan normal. Maka regresi memenuhi asumsi normalitas.

\section{b. Uji Heteroskedasitas}

Pengujian heteroskedasitas dilakukan dengan menggunakan Scatterplot regresi, jika titik-titik menyebar dengan pola yang tidak jelas diatas dan dibawah 0 pada sumbu Y maka tidak terjadi masalah heteroskedasitas. Hasil uji heteroskedasitas dapat dilihat melalui Scatterplot pada gambar 4.3. 


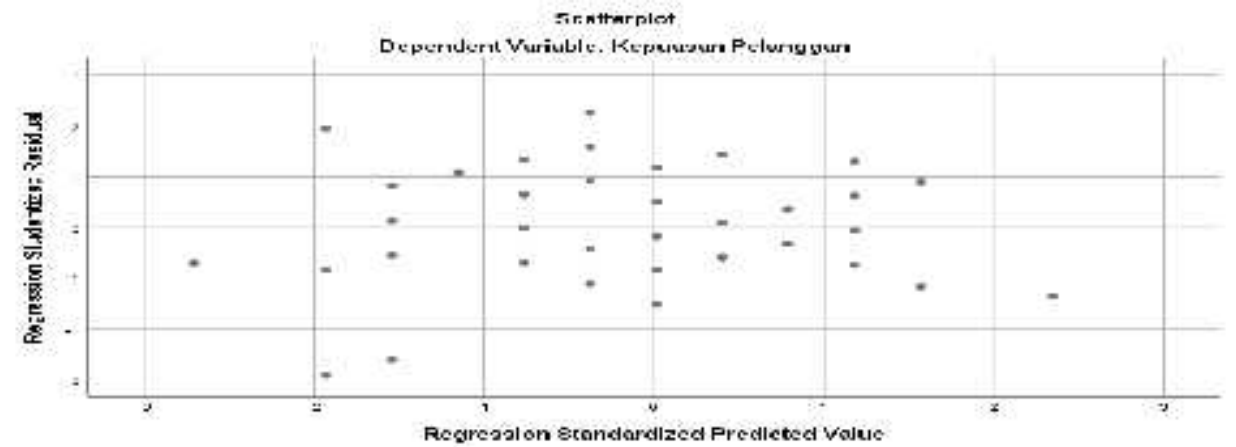

Gambar Scatterplot diatas dapat disimpulkan bahwa titik-titik menyebar secara acak baikdiatas maupun dibawah nol pada sumbu Y dan tidak membentuk sesuatu pola tertentu. Dengan demikian dapat disimpulkan bahwa tidak terjadi heteroskedasitas pada model regresi dalam penelitian ini.

\subsubsection{Analisis Regresi Linear Sederhana}

Analisis regresi linier sederhana digunakan untuk menguji sifat hubungan sebab-akibat antara variabel independen (X) terhadap variabel dependen (Y) yang diformulasikan dalam bentuk persamaan sebagai berikut: $\mathrm{Y}=\mathrm{a}+\mathrm{bX}$. Analisis regresi linear sederhana digunakan untuk melihat pengaruh kualitas pelayanan terhadap kepuasan pelanggan toko online Lazada di Kecamatan Sukarami Palembang dapat dilihat dari tabel di bawah

Tabel 4. 6

Hasil Analisis Regresi Linear Sederhana Coefficients $^{\mathrm{a}}$

\begin{tabular}{|c|c|c|c|c|c|c|}
\hline \multirow{2}{*}{\multicolumn{2}{|c|}{ Model }} & \multicolumn{2}{|c|}{ Unstandardized Coefficients } & \multirow{2}{*}{$\begin{array}{c}\text { Standardized } \\
\text { Coefficients } \\
\text { Beta }\end{array}$} & \multirow[b]{2}{*}{$\mathrm{t}$} & \multirow[b]{2}{*}{ Sig. } \\
\hline & & $\mathrm{B}$ & Std. Error & & & \\
\hline \multirow[t]{2}{*}{1} & (Constant) & 3,130 & 2,136 & & 1,465 & , 148 \\
\hline & Kualitas Pelayanan & 612 & ,076 & ,726 & 8,039 & 000 \\
\hline
\end{tabular}

a. Dependent Variable: Kepuasan Pelanggan

Sumber: Data primer yang diolah dengan SPSS 25.0, 2021

Dari tabel 4.6 dapat dilihat bahwa hasil analisis yang telah dilakukan mendapatkan persamaan regresi linear sederhana yaitu sebagai berikutY $=3,130+0,612 \mathrm{X}$. Interpretasi model regresi Konstanta $(\alpha)=$ 3,130 (Mengandung arti bahwa nilai konsisten variabel partisipasi adalah sebesar 3,130).Koefisien regresi $\mathrm{X}=0,612$ (Menyatakan bahwa variabel kualitas pelayanan (X) dengan koefisien 0,612 berpengaruh terhadap kepuasan pelanggan (Y) toko online Lazada.

\subsubsection{Pengujian Hipotesis}

a. Uji t (Uji Parsial)

Uji t yaitu suatu uji untuk mengetahui signifikansi pengaruh variabel independen (kualitas pelayanan) secara parsial atau individual terhadap variabel dependen (kepuasan pelanggan). Hasil uji t dapat dilihat pada tabel berikut ini. 


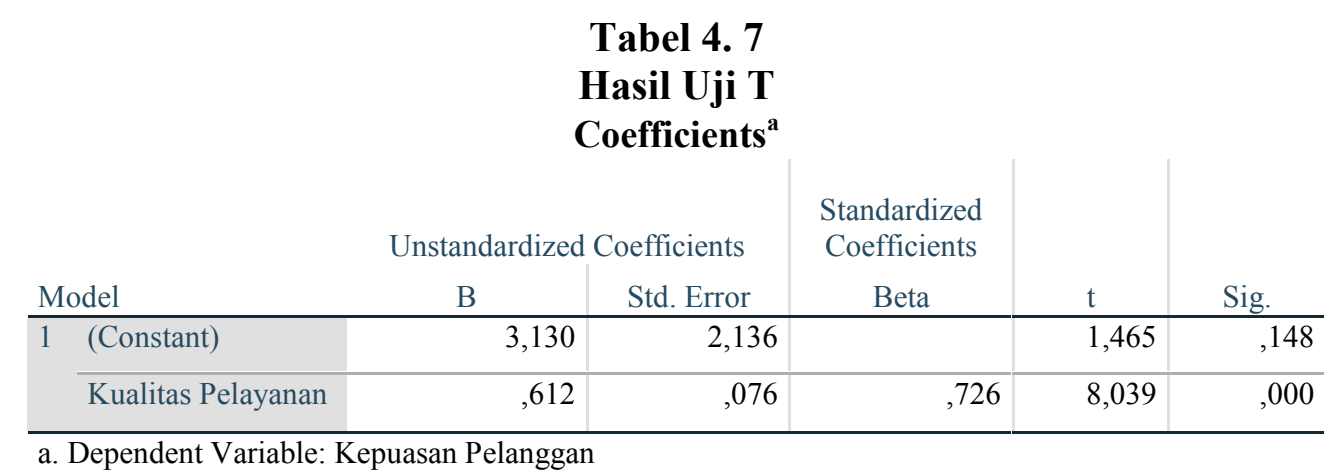

Sumber: Data primer yang diolah dengan SPSS 25.0, 2021

Tabel diatas dapat dilihat bahwa nilai thitung variabel kualitas pelayanan (X) lebih besar dari ttabel $(8,039>2,00247)$ dengan tingkat signifikasi 0,000 maka $\mathrm{Ho}$ ditolak dan $\mathrm{Ha}$ diterima. Artinya kualitas pelayanan berpengaruh terhadap kepuasan pelanggan.

\section{b. Interpretasi Koefisien Determinasi}

Interpretasi determinan digunakan untuk mengetahui seberapa besar pengaruh variabel bebas terhadap variabel terikatnya. Nilai determinasi untuk variabel bebasdapat dilihat pada tabel 4.8 .

Tabel 4.8

Hasil Uji R Model Summary ${ }^{b}$

\begin{tabular}{lr|r|r|r} 
Model & $\mathrm{R}$ & R Square & \multicolumn{1}{c|}{$\begin{array}{c}\text { Adjusted R } \\
\text { Square }\end{array}$} & $\begin{array}{c}\text { Std. Error of the } \\
\text { Estimate }\end{array}$ \\
\hline 1 &, $726^{\mathrm{a}}$ &, 527 &, 519 & 1,502 \\
\hline
\end{tabular}

a. Predictors: (Constant), Kualitas Pelayanan

b. Dependent Variable: Kepuasan Pelanggan

Sumber: Data primer yang diolah dengan SPSS 25.0, 2021

Berdasarkan tabel 4.8 nilai R Square sebesar 0,527 atau $52,7 \%$ yang artinya variabel kualitas pelayanan $(\mathrm{X})$ berpengaruh secara signifikan terhadap kepuasan pelanggan.

\subsection{Pembahasan}

Berdasarkan penelitian yang dilakukan oleh peneliti diperoleh; penelitian ini bertujuan untuk mengetahui analisis kualitas pelayanan terhadap kepuasan pelanggan toko online Lazada pada masyarakat Kecamatan Sukarami Palembang. Maka dalam penelitian ini hasil diperoleh dengan menyebarkan kuesioner yang dibuat dengan google formulir. Peneliti melakukan pengujian analisis data dengan menggunakan program SPSS versi 25. Berdasarkan hasil yang diperoleh diketahui bahwa kualitas pelayanan berpengaruh positif terhadap kepuasan pelanggan toko online Lazada. Diketahui sebagian besar masyarakat Kecamatan Sukarami yang berbelanja di toko online Lazada berjenis kelamin Perempuan, dan berusia 23-29 tahun.

Hasil dari penelitian yang dilakukan variabel kualitas pelayanan (X) berpengaruh terhadap variabel kepuasan pelanggan (Y). dari hasil pengujian hipotesis secara parsial melalui uji $\mathrm{t}$ diperoleh Thitung yaitu variabel kualitas pelayanan (X) lebih besar dari Ttabel $(8,039>$ $2,00247)$ dengan tingkat signifikansi 0,000 maka $\mathrm{H}_{0}$ ditolak dan $\mathrm{Ha}$ diterima, artinya kualitas pelayanan berpengaruh positif terhadap kepuasan pelanggan toko online Lazada.

Hasil pengujian regresi linier sederhana terbentuk persamaan $\mathrm{Y}=3,130+$ 
$0,612 \mathrm{X}$, dengan nilai koefisien determinasi $\left(\mathrm{R}^{2}\right)$ sebesar 0,527 atau $52,7 \%$. Hal ini menunjukkan bahwa kualitas pelayanan dapat menjelaskan kepuasan pelanggan sebesar 52,7\% sedangkan sisanya $47,3 \%$ dijelaskan oleh variabel lain yang tidak termasuk dalam penelitian ini.

\section{PENUTUP}

\subsection{Kesimpulan}

Penelitian ini secara keseluruhan menyimpulkan kualitas pelayanan berpengaruh secara positif dan signifikan terhadap kepuasan pelanggan toko online Lazada. Hasil pengujian hipotesis diperoleh nilai thitung variabel kualitas pelayanan $(\mathrm{X})$ lebih besar dari t tabel $(8,039>$ 2,00247) dengan tingkat signifikasi 0,000 maka $\mathrm{H}_{0}$ ditolak dan $\mathrm{H}_{a}$ diterima. Artinya kualitas pelayanan berpengaruh terhadap kepuasan pelanggan. Analisis yang telah dilakukan mendapat persamaan regresi linear sederhana yang terbentuk $\mathrm{Y}=3,130+0,612 \mathrm{X}$ dimana variabel kualitas pelayanan berpengaruh terhadap kepuasan pelanggan toko online Lazada. Berdasarkan tabel 4.8 diperoleh nilai $\mathrm{R}$ Square sebesar 0,527 atau $52,7 \%$ sehingga dapat disimpulkan bahwa variabel kualitas pelayanan (X) berpengaruh secara signifikan terhadap kepuasan pelanggan, sedangkan sisanya 47,3\% dapat dipengaruhi oleh faktor-faktor lain yang tidak dibahas dalam penelitian ini.

\subsection{Saran}

Berdasarkan penelitian yang dilakukan, maka penulis mengemukakan saran sebagai berikut:

a. Toko online Lazada hendaknya lebih memperhatikan dan memberikan pelayanan yang baik untuk pelanggan toko online Lazada serta menanggapi keluhan pelanggan, karena hal ini sangat penting bagi Lazada untuk meningkatkan minat beli ulang.

b. Pihak toko online Lazada hendaknya memberikan informasi yang tepat, cepat dan cermat kepada pelanggan yang menggunakan toko online Lazada dan memperjelas waktu pengiriman produk yang dipesan.

\section{DAFTAR PUSTAKA}

Ahmad, S. (2017). Analisis Pengaruh Penerapan E-commerce dan Kualitas Pelayanan terhadap Kepuasan Konsumen. Jurnal Manajemen Bisnis STIE IBBI.

Andra, T. (2018). Metode Penelitian. Yogyakarta: Penerbit Yogyakarta.

Arikunto, S. (2013). Prosedur PenelitianSuatu Pendekatan Praktik. Jakarta: Rineka Cipta.

Bernard, A. S. (2012). An Introduction to Enterprise Architecture. Bloomington: AuthorHouse.

Cahyani, E., \& Setiani, D. (2013). Pengaruh motivasi dan kepuasan kerja terhadap kualitas pelayanan internal tenaga pendidik pada politeknik swasta di Sumatera Selatan. Jurnal Administrasi Bisnis, 1 (1): 1-16.

Chandra, Gregorius, D. (2011). Service, Quality \& Satisfaction, Edisi 3. Yogyakarta: Andi.

Christy, F. E. (2020). Top 10 E-commerce di Indonesia Kuartal I 2020. Tempo.Co. https://data.tempo.co/data/907/top-10-ecommerce-di-indonesia-kuartal-i-2020. diakses 5 April 2021.

E-commerce, S. (2020). Jumlah Pengguna Ecommerce Indonesia di Tahun 2020 Meninggkat Pesat. Sirclo.Com. https://www.sirclo.com/jumlah-penggunae-commerce-indonesia-di-tahun-2020meningkat-pesat/. diakses pada 14 Maret 2021.

Ferdinand, A. (2014). Metode Penelitian 
Manajemen. Semarang: Badan Penerbit Universitas Diponegoro.

García Reyes, L. E. (2013). uji Asumsi Klasik. Journal of Chemical Information and Modeling.

Ghozali, I. (2018). Aplikasi Analisis Multivariate dengan Program IBM SPSS 25. Semarang: Universitas Diponegoro.

Hanif, M. (2013). Marketing Research: Panduan Bagi Manajer, Pimpinan Perusahaan Organisasi. Jakarta:Elex Media Komputindo.

Hardiansyah. (2011). Kualitas Pelayanan Publik. Yogyakarta: Gava Media.

Husein, U. (2013). Metode Penelitian untuk Skripsi dan Tesis. Jakarta: Rajawali.

Irawan, H. (2009). 10 Prinsip Kepuasan Pelanggan. Jakarta: Elex Media Komputindo.

Kementerian Kesehatan Republik Indonesia. (2016). Gambaran Objek Penelitian.

Kompas.com. (2021). Jumlah pengguna internet Indonesia 2021 tembus 202 juta. Kompas.Com.

https://tekno.kompas.com/read/2021/02/2 3/16100057/jumlah-pengguna-internetindonesia-2021-tembus-202-juta. diakses pada 25 Maret 2021.

Kotler, P. and K. L. K. (2016). Marketing Management (15th Editi). New Jersey: Pearson Pretice Hall, Inc.

Lupiyoadi. (2006). Manajemen Pemasaran Jasa Edisi Kedua. Jakarta: Salemba Empat.

Muhadjir, N. (1996). Metodologi Penelitian Kualitatif. Yogyakarta: Rake Sarasisn.

Nabila, M. (2021). Statistik Perkembangan Industri E-commerce sepanjang 2020.
DailySocial.Id.

dailysocial.id/post/statistik-

perkembangan-industri-e-commerce-

sepanjang-2020. diakses pada 6 April 2021.

Nasution, J. R. (2019). Analisis Kualitas Pelayanan Terhadap Kepuasan Pelanggan Toko Online Lazada (Studi Kasus Mahasiswa FEBI Angkatan 2014 UIN Sumatera Utara).

Nasution, M. N. (2004). Manajemen Transportasi. Jakarta: Ghalia Indonesia.

Natanael, S. (2013). Mahir Menggunakan SPSS Secara Otodidak. Jakarta: Kompas Gramedia.

Nazir, M. (2013). Metode Penelitian, Bogor: Ghalia Indonesia.

Nurdian, G. (2020). E-Commerce Indonesia Tahun 2020. Era Digital Mendominasi. Grahanurdian.Com. https:/grahanurdian.com/e-commerceindonesia-tahun-2020/. diakses pada 6 April 2021

Payne, A. (2000). Pemasaran Jasa, The Essence of Service Maerketing. Yogyakarta: Andi.

Saleh. (2010). Kualitas Pelayanan (Edisi Pert). Jakarta: Universitas Indonesia.

Sugiyono. (2017). Metode Penelitian Kuantitatif, Kualitatif dan $R \& D$. Bandung: Alfabeta.

Tjiptono, F. (2015e). Strategi Pemasaran. Yogyakarta: ANDI.

Tse dan wilton. (2008). Kepuasan Pelanggan, Jilid 2 (Edisi Ketiga). Jakarta: Indeks Kelompok Gramedia.

Yudiatmaja. (2013). Analisis Regresi dengan Menggunakan Aplikasi Komputer Statistik SPSS. Jakarta: Gramedia. 